\title{
Short-Term Outcome of Mechanical Ventilation in Neonates
}

\author{
Gurubacharya SM${ }^{1}$, Aryal DR ${ }^{2}$, Misra $M^{3}$, Gurung $\mathbf{R}^{4}$
}

${ }^{1}$ Dr. Simmi Misra Gurubacharya, MBBS, MD, Registrar, Assistant Professor (NAMS), ${ }^{2}$ Dr. Dhana Raj Aryal, Consultant Pediatrician and Neonatologist, ${ }^{3}$ Dr. Megha Mishra, MBBS, Medical Officer, ${ }^{4}$ Dr. Roshma Gurung, MBBS, Medical Officer, NICU, All from the Paropakar Maternity and Women's Hospital, Thapathali, Kathmandu, Nepal

Address for Correspondence: Dr. Simi Misra Gurubacharya, E-mail: sm_pul@rediffmail.com

\begin{abstract}
Mechanical ventilation of newborn has been practiced for several years with several advances made in the way. As compared to the Western world and our neighbouring countries, neonatal ventilation in our country is still in its infancy. Objectives: To analyze the common indications and outcome of neonates requiring mechanical ventilation. Methods: This was a prospective observational study conducted on neonates requiring mechanical ventilation within first 24 hours of birth over a period of nine months. Results: Birth asphyxia was the commonest indication for ventilation (59.67\%) followed by asphyxia with meconium aspiration syndrome (MAS) (17.74\%), hyaline membrane disease (HMD) (8.06\%), MAS $(6.45 \%)$ and intrauterine pneumonia (6.45\%). Out of 62 babies, 22 (35.48\%) survived. Babies with asphyxia had highest survival rate (51.35\%). Neonates with HMD did not survive. Term babies and babies weighing $\geq 2500 \mathrm{~g}$ had higher survival rate of $40.47 \%$ and $41.46 \%$ respectively, while babies less than 32 weeks had survival rate of $16.66 \%$ only. Conclusions: Mechanical ventilation reduces the neonatal mortality; hence, facilities for neonatal ventilation should be included in the regional and central hospitals providing level II neonatal care.
\end{abstract}

Key words: neonatal ventilation, hyaline membrane disease, low birth weight

\section{Introduction}

$\mathrm{M}$ echanical ventilation of newborn has been practiced for several years with several advances made in the way. It was introduced in 1960s to support the infants with respiratory failure. Mechanical ventilation may be immediately required in multiple conditions of a sick newborn. This has contributed to the rapid decline in neonatal mortality in various parts of the world. As compared to the Western world and our neighbouring countries, neonatal ventilation in our country is still in its infancy. The basic infrastructure and expertise to ventilate newborn is lacking in majority of the hospitals. Hence, there is a scanty data on neonatal ventilation in Nepal. The study was done to find out the indications and outcome of neonates requiring mechanical ventilation in first 24 hours of birth.

\section{Materials and Methods}

This was a prospective study done from January 2009 to September 2009. Sixty two newborns were enrolled requiring mechanical ventilation within first 24 hours of birth. Babies with severe congenital anomalies were excluded. All neonates were born in our hospital. The neonate's birthweight, gestational age, apgar score, age of onset of respiratory distress, time of intubation and extubation, course of illness and cause of death were recorded. Outcomes of main interest were:

1. Common conditions requiring mechanical ventilation.

2. Survival of ventilated babies (NICU mortality).

3. Survival rate in different clinical conditions.

4. Survival rate in relation to birth weight and gestational age.

All the ventilated babies were nursed under servo controlled open care system. They were continuously under monitor for heart rate, respiratory rate, temperature, ECG, blood pressure and oxygen 
saturation. They were diagnosed by standard criteria for asphyxia ${ }^{1}$, meconium aspiration syndrome (MAS)2 hyaline membrane disease $(\mathrm{HMD})^{2}$, intrauterine pneumonia ${ }^{3}$ and congenital heart disease ${ }^{4}$.

\section{The indications for IPPV were}

(i) Respiratory distress with failure to maintain arterial blood gases (ABGs) under head-box or mask with FiO2 of $0.6-0.8(\mathrm{pH}<7.2$ and/or $\mathrm{PaCO} 2>60 \mathrm{mmHg}$ and/or $\mathrm{PaO} 2<50 \mathrm{mmHg}$ )

(ii) Prolonged/recurrent apneic spells and

(iii) Downes' score (5) $>6$.

The ventilator used was time-cycled, pressure limited continuous flow ventilator (Scherist, Infant Ventilator, Model. Millenium, Classl, Type B). The objective was to ventilate the babies effectively (maintaining normal ABGs with minimal work of breathing) with minimal ventilator settings. Oxygen saturation was maintained between $87-93 \%$. Septic screening was done in all babies. First line antibiotics used were cefotaxime and amikacin. Other drugs (eg. vancomycin, ceftazidime, meropenem, dopamine, phenobarbitone, frusemide) were used when required.

\section{Results}

A total of sixty two babies were mechanically ventilated. There were 41 males and 21 females (ratio $2: 1$ ). The mean birth weight and gestational age were $2588.95 \mathrm{~g}$ (range 950-3800g) and 37.4 weeks (28-42wks) respectively. Out of 62 babies, twenty two (35.48\%) survived. Table 1 shows the survival of ventilated babies in relation to birth weight. The maximum number of ventilated babies was in the group weighing $\geq 2500 \mathrm{~g}$ $(66.13 \%)$. Table 2 shows the survival of ventilated babies in relation to gestational age. Neonates of more than 32 weeks and less than 37 weeks had $30.76 \%$ of survival rate in comparison to survival rate of $16.66 \%$ in those less than 32 weeks of gestation. Full-term babies had $40.47 \%$ of survival rate. Table 3 shows the indications for mechanical ventilation and survival in different clinical conditions. Perinatal asphyxia contributed to the maximum number (59.68\%). There was one case of cyanotic congenital heart disease which did not survive. Only one case of asphyxia with MAS survived (9.09\%), while nineteen cases (51.35\%) of asphyxia survived out of thirty seven babies. HMD contributed to $8.06 \%$ of cases followed by MAS and intrauterine pneumonia (6.45\% each). None of the babies with HMD survived.
Table 1: Survival of ventilated neonates in relation to birth weight.

\begin{tabular}{|l|c|c|}
\hline Weight(g) & $\begin{array}{c}\text { Ventilated: } \\
\text { Number (\%) }\end{array}$ & $\begin{array}{c}\text { Survived: } \\
\text { Number (\%) }\end{array}$ \\
\hline$<1000$ & $1(1.62 \%)$ & $0(0 \%)$ \\
\hline $1000-1499$ & $4(6.45 \%)$ & $1(25 \%)$ \\
\hline $1500-1999$ & $8(12.9 \%)$ & $2(25 \%)$ \\
\hline $2000-2499$ & $8(12.9 \%)$ & $2(25 \%)$ \\
\hline$\geq 2500$ & $41(66.13 \%)$ & $17(41.46 \%)$ \\
\hline Total & $\mathbf{6 2 ( 1 0 0 \% )}$ & $\mathbf{2 2 ( 3 5 . 4 8 \% )}$ \\
\hline
\end{tabular}

Table 2: Survival of ventilated neonates in relation to gestational age

\begin{tabular}{|l|c|c|}
\hline $\begin{array}{l}\text { Gestation Age } \\
\text { (wks) }\end{array}$ & $\begin{array}{c}\text { Ventilated: } \\
\text { Number (\%) }\end{array}$ & $\begin{array}{c}\text { Survived: } \\
\text { Number (\%) }\end{array}$ \\
\hline$<28$ & $1(1.62 \%)$ & $0(0 \%)$ \\
\hline $28<32$ & $6(9.68 \%)$ & $1(16.66 \%)$ \\
\hline $32<37$ & $13(20.96 \%)$ & $4(30.76 \%)$ \\
\hline$\geq 37$ & $42(67.74 \%)$ & $17(40.47 \%)$ \\
\hline Total & $\mathbf{6 2 ( 1 0 0 \% )}$ & $\mathbf{2 2 ( 3 5 . 4 8 \% )}$ \\
\hline
\end{tabular}

Table 3: Indications and survival in different clinical conditions

\begin{tabular}{|l|c|c|}
\hline Indications & $\begin{array}{c}\text { Ventilated } \\
\mathbf{n}(\mathbf{\%})\end{array}$ & $\begin{array}{c}\text { Survived } \\
\mathbf{n}(\mathbf{\%})\end{array}$ \\
\hline Asphyxia & $37(59.68 \%)$ & $19(51.35 \%)$ \\
\hline $\begin{array}{l}\text { Asphyxia with } \\
\text { MAS }\end{array}$ & $11(17.74 \%)$ & $1(9.09 \%)$ \\
\hline HMD & $5(8.06 \%)$ & $0(0 \%)$ \\
\hline MAS & $4(6.45 \%)$ & $1(25 \%)$ \\
\hline Pneumonia & $4(6.45 \%)$ & $1(25 \%)$ \\
\hline Others & $1(1.62 \%)$ & $0(0 \%)$ \\
\hline Total & $\mathbf{6 2 ( 1 0 0 \% )}$ & $\mathbf{2 2 ( 3 5 . 4 8 \% )}$ \\
\hline
\end{tabular}

\section{Discussion}

The survival rate of ventilated babies was $35.48 \%$. The survival rate in different studies in different parts of the world were $48.76 \%^{6}, 55.5 \%{ }^{7}, 51 \%^{8}, 46.54 \%^{9}$, $53 \%{ }^{10}, 43.9 \%{ }^{11}$ and $52.9 \%{ }^{12}$ respectively. However, these different studies also included CPAP as the mode of ventilation whereas we used it if required during weaning only. The maximum number of ventilated babies falls in the group weighing $\geq 2500 \mathrm{~g}$ (66.13\%). The survival rate $(41.46 \%)$ was also high in this group. Survival in all the babies between $1000 \mathrm{~g}$ to $2499 \mathrm{~g}$ was $25 \%$ only. This result is not in accord with other studies $^{9,13}$ demonstrating increase in survival with increasing birth weight, although the babies in the group weighing $\geq 2500 \mathrm{~g}$ had higher survival rate. This result may be because of the small sample size of our study. Though the number of admissions was more, but due to 
the limited numbers of ventilators other babies fulfilling the criteria could not be included. The study documents the increase in survival rate with increasing gestational age with maximum survival rate in the full term babies $(40.47 \%)$. Babies less than 32 week had survival rate of $16.66 \%$ while other studies had shown $25 \%-32 \%$ of survival rate ${ }^{8,13}$. In another study, the survival rate of babies with gestational age more than 37 weeks was $50.2 \%{ }^{9}$

Almost $34 \%$ of low birth weight babies (LBW) required mechanical ventilation within first 24 hours of birth. Out of all the LBW babies, $23.8 \%$ survived as compared to $41.46 \%$ of babies in the group of $\geq 2500 \mathrm{~g}$. Our one newborn of gestation less than 28 weeks and weighing $950 \mathrm{~g}$ kept on ventilator did not survive. Sepsis is a major complication leading to high mortality and poor survival of LBW babies. Also, neonates on ventilator require extra care and monitoring which in our set up is quite difficult due to discrepant ratio between neonates and nursing staff.

Perinatal asphyxia was the main indication of ventilation followed by asphyxia with MAS (17.74\%), HMD (8.06\%), MAS (6.45\%), congenital pneumonia $(6.45 \%)$ and congenital heart disease (1.62\%). Asphyxia was the main indication of ventilation in one of the study ${ }^{8}$. However in majority of the other studies, HMD was the main indication of ventilation ${ }^{6,7,9,11,12}$. The survival rate for asphyxia was $51.35 \%$ while the other studies show $31.8 \%^{6}, 66.6 \%^{14}, 42 \%^{8}, 27.2 \%^{13}$, and $46 \%{ }^{10}$ of survival rate. None of the babies with HMD survived. Two babies who were successfully extubated expired on day five and six of life due to nosocomial sepsis. The outcome of HMD in other studies ranged from $11.1 \%$ to $53.1 \% 8,12,13,14$. The reasons for the poor outcome of HMD and low LBW survival can be (i) lack of surfactant therapy, (ii) high rate of nosocomial infection, (iii) lack of other modes of assisted ventilation, (iv) organ immaturity of very low birth weight and extremely low birth weight babies and ( $v$ ) lack of effective monitoring while on ventilator. Other studies have also shown the risk factors for poor outcome are birth weight <2000gm, prematurity and late referrals to $\mathrm{NICU}^{11}$.

Babies with MAS and asphyxia with MAS too had poor survival rate. The late referral of mothers and delayed diagnosis of fetal distress lead to severe asphyxia and meconium aspiration which further contribute to persistent pulmonary hypertension of newborn (PPHN) leading to high mortality. Use of high frequency ventilation, NO and ECMO could decrease the morbidity and mortality if available.
The present time is switching to noninvasive modes of ventilation. We still are a century behind in the mechanical ventilation. Because of the lack of nasal CPAP we could not include CPAP as mode of ventilation in our study which certainly would have changed the survival rate. Still judicious use of IPPV improves the outcome in babies having RDS and MAS. Use of IPPV has certainly increased the survival rate in different clinical conditions wherever required. Ventilation has to be used in the early part of illness before the start of metabolic complications or organ damage. Also, aspesis is to be maintained strictly, otherwise it makes all our effort in vain.

For the improved outcome i.e. to decrease the morbidity and mortality of newborns requiring ventilator care, we need to improve our resources and neonatal intensive care services with an appropriate ratio between sick neonate and medical staff.

The aim of ventilation is not only to decrease the morbidity and mortality but also to be used judiciously to prevent the complications. To decrease our neonatal mortality, we require assisted ventilation which is a team effort of skilled, devoted doctors and nursing staff and as we gain experience in the ventilation our outcome would also improve.

\section{Conclusion}

Mechanical ventilation reduces the neonatal mortality; hence, facilities for neonatal ventilation should be included in the regional and central hospitals providing level II neonatal care.

\section{Acknowledgements: None \\ Funding: None \\ Conflict of Interest: None \\ Permission from IRB: Yes}

\section{References}

1. Adcock LM, Papile LA. Perinatal Asphyxia. In Manual of Neonatal care, $6^{\text {th }}$ edn. Eds. Cloherty JP, Eichenwald EC, Stark AR. Philadelphia, Lippincott Williams \& Wilkins, 2008, pp 518-523.

2. Whitsett JA, Rice WR, Warner BB, Wert SE, Pryhuber GS. Acute Respiratory Disorders. In: Avery's Neonatology Pathophysiology and Management of the Newborn, $6^{\text {th }}$ edn. Eds. Macdonald GM, Seshia Mary MK, Mullett MD. $6^{\text {th }}$ edition Philadelphia, Lippincott Williams \& Wilkins, 2005, pp 560-563. 
3. Singh M. Respiratory Disorders. In Care of the newborn, $6^{\text {th }}$ edn. Ed. Singh M. Sagar Publications, 2004. pp 266-268.

4. Wechsler SB, Wernovsky G. Cardiac Disorders. In Manual of Neonatal care, $6^{\text {th }}$ edn. Eds. Cloherty JP, Eichenwald EC, Stark AR. Philadelphia, Lippincott Williams \& Wilkins, 2008, pp 388-400.

5. Wood DW, Downes' JJ, Locks HI. A clinical score for the diagnosis of respiratory failure. Am J Dis Child 1972;123:227-229.

6. Maiya PP, Vishwanath D, et al. Mechanical ventilation of newborns: Experience from a level II NICU. Indian Pediatr 1995:32:1275-1280.

7. Singh M, Deorari AK, Paul VK, et al. Three year experience with neonatal Ventilation from a tertiary care hospital in Delhi. Indian Pediatr 1993;30:783789.

8. Riyas PK, Vijayakumar KM, Kulkarni ML. Neonatal mechanical ventilation. Indian J Pediatr 2003;70:537-540.
9. Nangia S, Saili A, Dutta AK, et al. Neonatal mechanical ventilation-experience at a level II care centre. Indian J Pediatr 1998;65:291-296.

10. Lindroth $M$, Svenningsen NW, Ahlstrom $H$, Jonson B. Evaluation of mechanical Ventilation in newborn infants-I. Techniques and survival rates. Acta Paediatr Scand 1980 ;69:143-149.

11. Kishan J, Vaidez ME, Mir NA, Elzouki AY. Mechanical ventilation in newborn infants. Afr $J$ Med Sci 1988;17:83-88.

12. Trotman $H$, Barton $M$, Mitchell V. Outcome of neonates ventilated in the main intensive care unit at The University Hospital of the West Indies: a 15 year experience. Trop Doct 2007;37:249-250.

13. Krishnan L, Francis PP, D'souza NA, Bhaskaranand N. Assisted ventilation in neonates: the Manipal experience. Indian J Pediatr 1994;61:379-386.

14. Malhotra AK, Nagpal R, Gupta RK, Chhajita DS, Arora RK. Respiratory distress in newborn: treated with ventilation in a level II nursery. Indian Pediatr 1995;32:207-211.

\section{How to cite this article?}

Gurubacharya SM, Aryal DR, Misra M, Gurung R. Short-Term Outcome of Mechanical Ventilation in Neonates. J Nepal Paedtr Soc 2011;31(1):35-38. 